\title{
Ranitidine suspension or famotidine resoriblette and gastric fluid volume and $\mathrm{pH}$
}

We studied the effect of two new formulations of $\mathrm{H}_{2}$-receptor antagonists on gastric fluid pH and volume. Forty-five healthy, elective adult in-patients in three study groups, 15 in each, were premedicated using oral diazepam $10 \mathrm{mg}$ with $100 \mathrm{ml}$ of a dose of water soluble suspension of ranitidine $300 \mathrm{mg}$ with sodium citrate/bicarbonate, or a resoriblette of famotidine 40 $m$, or placebo. Gastric fluid samples were obtained by blind aspiration afier anaesthesia induction, 50-70 min from premedication, and again $90 \mathrm{~min}$ from premedication. After a mean period of 60 min from ingestion the patients medicated with $\mathrm{H}_{2}$-antagonists had higher gastric juice $\mathrm{pH}$ than those in the control group (1.5 (1.1-6.3), median (range)) $(P<0.0001)$ for ranitidine (6.8 (4.1-7.8)), $P<0.01$ for famotidine (3.9 (1.5-7.6)); $P<0.05$ ranitidine vs famotidine). Recovered volumes were similar for the groups (median 3-4 ml, range 0-50 ml). None of the $\mathrm{H}_{2}$ patients had $\mathrm{pH}<3.5$ and volume $\geq 0.3 \mathrm{ml} \cdot \mathrm{kg}^{-1}$ $(P<0.05$ vs placebo). In second aspirations, taken $90 \mathrm{~min}$ from premedication, the group differences from control in $\mathrm{pH}$ persisted. Famotidine patients had the lowest volumes $(P<0.05$ vs controls); yet one famotidine patient had a $\mathrm{pH}<2.5$ and volume $\geq 0.3 \mathrm{ml} \cdot \mathrm{kg}^{-1}$. It is concluded that, at the moment of oral anxiolytic premedication, ranitidine-buffer suspension effectively reduced gastric juice acidity, whereas famotidine resoriblette failed to increase reliably gastric $\mathrm{pH}$ in 50-90 min.

Les auteurs étudient les effets de deux préparations antagonistes des récepteurs $\mathrm{H}_{2}$ sur le $\mathrm{pH}$ et le volume gastriques. Quarantecinq adultes bien portants hospitalisés sont répartis en trois groupes de quinze et reçoivent du diazépam $10 \mathrm{mg}$ en prémédication suivi diune suspension de ranitidine $300 \mathrm{mg}$ dans 100

\section{Key words}

HISTAMINE: ranitidine, famotidine;

GASTROINTESTINAL TRACT: intragastric $\mathrm{pH}$ and volume; COMPLICATIONS: aspiration, acid gastrointestinal reflux.

From the Department of Anaesthesia, Maria Hospital, Surgical Services Unit of Helsinki City Health Department, Helsinki, Finland.

Address correspondence to: Dr. M. Oikkonen, Vilkenintie 21

D, 00640 Helsinki, SF-Finland.

Accepted for publication 23rd May, 1995. ml d'eau avec du bicarbonate/citrate de sodium ou un comprimé de famotidine $40 \mathrm{mg}$ ou un placebo. Les échantillons de liquide gastrique sont obtenus par aspiration à l'aveugle après linduction, 50 à 70 minutes après le prémédication et une fois de plus 90 minutes après la prémédication. Après un délai moyen de 60 minutes de lingestion, les patients qui ont reçu un antagoniste $\mathrm{H}_{2}$ ont un $\mathrm{pH}$ gastrique plus élevé que ceux du groupe contrôle (1,5 (1,1-6,3), médiane (écart)) $(P<$ $0,0001)$ pour la ranitidine $(6,8(4,1-7,8)), P<0,01$ pour la famotidine $(3,9(1,5-7,6)) ; P<0,05$ ranitidine vs famotidine). Le volume aspiré était le même pour les groupes (médiane 3-4 $\mathrm{ml}$, écart 0-50 $\mathrm{ml}$ ). Aucun des patients $\mathrm{H}_{2}$ n'avait un $\mathrm{pH}$ $<3.5$ et un volume $\geq 0,3 \mathrm{ml} \cdot \mathrm{kg}^{-1}$ ( $P<0,05$ vs placebo). $A$ une deuxième aspiration réalisée 90 min après la prémédication, les différences de $\mathrm{pH}$ entre les groupes comparativement aux contrôles persistent. Les patients sous famotidine ont les volumes les plus bas $(P<0,05$ vs contrôles); toutefois un patient du groupe famotidine avait un $\mathrm{pH}<2,5$ et un volume $\geq 0,3 \mathrm{ml} \cdot \mathrm{kg}^{-1}$. Les auteurs concluent qu'au moment de la prémédication orale anxiolytique, la suspension de ranitidine tamponnée réduit avec efficacité l'acidité gastrique, alors que la préparation de famotidine ne réussit pas à augmenter de façon constante le $\mathrm{pH}$ gastrique en 50-90 min.

Timely administration ${ }^{1}$ or repeated dosing ${ }^{2}$ of the oral $\mathrm{H}_{2}$-receptor antagonists ranitidine or famotidine have provided effective prophylaxis against gastric acid aspiration. However, to be effective, the timing of administration is crucial, and this may necessitate intravenous administration. ${ }^{1}$ An oral formulation producing a rapid and reliable effect would be attractive, because nurses are often not licensed to give $\dot{N}$ drugs. Such a formulation might also enable simultaneous administration of an oral sedative premedicant and improve flexibility of the surgical list.

Two modern formulations of $\mathbf{H}_{2}$-receptor antagonist have been registered for use in patients with gastroduodenal ulcers. A water soluble suspension of ranitidine (Zantac ${ }^{\circledR}$ effervescent granules, Glaxo) mixed with sodium citrate and sodium bicarbonate $(1230 \mathrm{mg}$ of each per $300 \mathrm{mg}$ ranitidine) gives rapid relief of gastritis symptoms. A lingual or buccal resoriblette of famotidine (Pep- 
cidin Rapitab $\left.{ }^{\circledR}, \mathrm{MSD}\right)$ dissolves rapidly in mouth, though its effect is dependent upon absorption of the swallowed drug, rather than on absorption through the oral mucosa. Our study aimed to answer, whether these two formulations administered one hour before induction of anaesthesia, would reduce gastric acidity.

\section{Methods}

The Ethic Committee of the institute approved the study protocol. Forty-five informed, consenting ASA 1-2 patients, aged 18-60 yr, scheduled for elective surgery and general anaesthesia participated in the study. Symptoms of, or medication for, any gastrointestinal disease, $>20 \%$ overweight, and abdominal surgery were exclusion criteria. The patients were randomized to receive either ranitidine (Group R), famotidine (Group F) or placebo (Group $\mathrm{C}=$ control) preparations. (Table I).

The patients were fasted after midnight. In each group, the patients received a diazepam tablet, $10 \mathrm{mg}$, which was washed down with the ranitidine suspension, or a placebo suspension, and followed by a resoriblette, applied between tongue and buccal mucosa. The patients were taught to apply the resoriblette correctly at the preanaesthetic visit using a placebo sample, and they were instructed to swallow the remaining saliva after the resoriblette had dissolved. The dosing was targeted to occur $60 \mathrm{~min}$ preceding anaesthesia induction to allow 50-70 min until the first aspiration. The Group $C$ patients received $100 \mathrm{ml}$ glucose in water suspension, the volume, colour, taste, and $\mathrm{pH}(5.8)$ of which paralleled that of the active ranitidine preparation ( $\mathrm{pH}$ 6.4). Thereafter, they received an oral placebo resoriblette resembling active famotidine. The Group $\mathrm{R}$ patients received a powder of ranitidine (Zantac ${ }^{\circledR}$, Glaxo), $300 \mathrm{mg}$, suspended in 100 $\mathrm{ml}$ water, and a placebo resoriblette. The Group $\mathrm{F}$ patients received a resoriblette of famotidine (Pepcidin ${ }^{\circledR}$, MSD), $40 \mathrm{mg}$, after the placebo suspension.

Following three minutes preoxygenation, anaesthesia was induced using propofol and fentanyl. A rapid sequence tracheal intubation was facilitated by succinylcholine without mask ventilation. Vecuronium was used to provide further muscle relaxation, and anaesthesia was maintained with enflurane in nitrous oxide $70 \%$ and oxygen, supplemented with fentanyl. A 25 French gauge (Ch 25) multiorificed orogastric tube was inserted until its tip met firm resistance. The tip position was confirmed by epigastric auscultation of $5 \mathrm{ml}$ injected air. Thereafter the gastric contents were evacuated carefully using a $50 \mathrm{ml}$ syringe while an assistant compressed the epigastrium three times in each of the following positions: (1) supine, (2) slight (about $15^{\circ}$ ) left lateral tilt, (3) $15^{\circ}$ head-down tilt added, (4) tilting to the right, (5) head-down tilt off, and (6) repeated supine. The tube was drawn out while
TABLE I Clinical characteristics of the study groups

\begin{tabular}{lccc}
\hline Group & $\begin{array}{c}\text { Control } \\
(n=15)\end{array}$ & $\begin{array}{c}\text { Ranitidine } \\
(n=15)\end{array}$ & $\begin{array}{l}\text { Famotidine } \\
(n=15)\end{array}$ \\
\hline Sex (F/M) & $11 / 4$ & $13 / 2$ & $12 / 3$ \\
Age (yr) & $51 \pm 5$ & $46 \pm 9$ & $45 \pm 9$ \\
Weight (kg) & $72 \pm 11$ & $71 \pm 12$ & $70 \pm 14$ \\
Height (cm) & $170 \pm 9$ & $169 \pm 7$ & $168 \pm 9$ \\
Smoking (+/-) & $5 / 10$ & $6 / 9$ & $5 / 10$ \\
Premedication to (min) & & & \\
- First aspiration & $61 \pm 6$ & $59 \pm 4$ & $60 \pm 8$ \\
- Second aspiration & $91 \pm 1$ & $91 \pm 2$ & $91 \pm 1$ \\
Propofol (mg) & $151 \pm 24$ & $154 \pm 26$ & $148 \pm 20$ \\
Fentanyl given till second & & & \\
$\quad$ sampling $(\mu \mathrm{g})$ & $130 \pm 41$ & $110 \pm 51$ & $123 \pm 59$ \\
\hline
\end{tabular}

Values are mean $\pm \mathrm{SD}$, or number.

applying suction, and, after emptying, sited again in the oesophagus. At $90 \mathrm{~min}$ from the premedication it was reinserted to the original depth, and a second sample was aspirated (without positioning or epigastric pressure), primarily for the determination of $\mathrm{pH}$.

The $\mathrm{pH}$ was immediately determined using indicator paper (Acilit ${ }^{\circledR}$, Art 9531, Merck, Germany), and later with a digital pH meter (Knick GWB pH-Meter $761 \mathrm{Ca}$ limatic, Knick, Germany). The results were in good agreement and the $\mathrm{pH}$ meter readings were chosen for analysis. When there was insufficient volume $(<0.5 \mathrm{ml})$ for analysis with the electronic $\mathrm{pH}$ meter, the $\mathrm{pH}$ results obtained with indicator paper were discarded, due to uncertainty whether the fluid was gastric juice, mucus or saliva. For statistical purposes, negative aspirations were tabulated as zero ml. Patients were considered "at risk" for gastric acid aspiration, if they had $\mathrm{pH}<2.5$ and volume $\geq 0.3 \mathrm{mg} \cdot \mathrm{kg}^{-1}$.

The demographic variables and time intervals were analyzed using ANOVA and Dunnet's test. The $\mathrm{pH}$ results were compared using Mann-Whitney U test. Frequencies were computed from contingency tables. $P<0.05$ indicated the level of statistical significance.

\section{Results}

Premedication times were equal among the groups (Table I). At $60 \mathrm{~min}$, compared with Group $\mathrm{C}, \mathrm{pH}$ was higher in group $\mathrm{R}(P<0.0001)$ and Group $\mathrm{F}(P<0.01)$, and the numbers of patients with $\mathrm{pH}<2.5$ were less $(P<0.0001$, and $<0.05$, respectively) (Table II). The volumes of gastric contents were similar. Volumes of $<0.5$ $\mathrm{ml}$ were obtained in three patients in each group. Compared with four patients in Group C, none of the patients was "at risk" after premedication with ranitidine or famotidine $(P<0.05)$. This difference validated also at a pH limit $<3.5(P<0.05)$.

The $\mathrm{pH}$ differences prevailed in the $90 \mathrm{~min}$ aspirations 
TABLE II Gastric juice $\mathrm{pH}$ and volume

\begin{tabular}{|c|c|c|c|c|c|c|}
\hline Group & Control & $n$ & Ranitidine & $n$ & Famotidine & $n$ \\
\hline \multicolumn{7}{|c|}{ First aspiration $(50-70 \mathrm{~min})$} \\
\hline $\begin{array}{l}\text { pH: median } \\
\text { (range) }\end{array}$ & $\begin{array}{l}1.5 \\
(1.1-6.3)\end{array}$ & 12 & $\begin{array}{l}6.8^{*} \\
(4.1-7.8)\end{array}$ & 12 & $\begin{array}{l}3.9 * \dagger \\
(1.5-7.6)\end{array}$ & 12 \\
\hline $\mathrm{pH}<2.5$ & 11 & 12 & $0^{*}$ & 12 & $5^{*}$ & 12 \\
\hline $\begin{array}{l}\text { Volume (ml): median } \\
\text { (range) }\end{array}$ & $\begin{array}{l}3 \\
(0-50)\end{array}$ & 15 & $\begin{array}{l}4 \\
(0-45)\end{array}$ & 15 & $\begin{array}{l}4 \\
(0-23)\end{array}$ & 15 \\
\hline Patients at risk $\ddagger$ & 4 & 15 & $0^{*}$ & 15 & $0^{*}$ & 15 \\
\hline \multicolumn{7}{|c|}{ Second aspiration $(90 \mathrm{~min})$} \\
\hline $\begin{array}{l}\text { pH: median } \\
\text { (range) }\end{array}$ & $\begin{array}{l}1.9 \\
(1.4-6.4)\end{array}$ & 13 & $\begin{array}{l}6.6^{*} \\
(4.2-7.8)\end{array}$ & 11 & $\begin{array}{l}6.7^{*} \\
(1.8-7.8)\end{array}$ & 11 \\
\hline $\mathrm{pH}<2.5$ & 7 & 13 & $0^{*}$ & 11 & 3 & 11 \\
\hline $\begin{array}{l}\text { Volume (ml) median } \\
\text { (range) }\end{array}$ & $\begin{array}{l}10 \\
(0-31)\end{array}$ & 15 & $\begin{array}{l}5 \\
(0-28)\end{array}$ & 15 & $\begin{array}{l}2.5^{*} \\
(0-28)\end{array}$ & 15 \\
\hline Patients at risk $\ddagger$ & 1 & 15 & 0 & 15 & 1 & 15 \\
\hline
\end{tabular}

Values are median and range, or number.

*Significantly different from Control Group.

†Significantly different from Ranitidine Group.

$\ddagger \mathrm{pH}<2.5$ and volume $\geq 0.3 \mathrm{ml} \cdot \mathrm{kg}^{-1}$.

between Group $\mathrm{R}$ and Group $\mathrm{C}(P<0.001)$, or Group $F$ and Group $C(P<0.01)$. In four cases in Group $\mathrm{C}$ and in one case in Group $\mathrm{F}, \mathrm{pH}$ increased from below to above 2.5. Group $F$ patients had lower volumes than those in Group $C(P<0.05)$, but the difference lost statistical significance, if the volumes were indexed to weight. One patient both in Groups $\mathrm{C}$ and $\mathrm{F}$ appeared to be "at risk," whether the $\mathrm{pH}$ limit was set at $<2.5$ or $<3.5$.

\section{Discussion}

Applying conventional risk limits for $\mathrm{pH}$ and volume, a third of the control patients were "at risk" for gastric acid aspiration during induction of anaesthesia. Ranitidine-buffer suspension effectively and rapidly raised $\mathrm{pH}$, whereas the $\mathrm{pH}$ increase after famotidine resoriblette was unsatisfactory.

Proposals towards more stringent safety criteria for $\mathrm{pH}$ (>3.5), and more liberal limits for volume have been recently suggested. ${ }^{3}$ If the $\mathrm{pH}$ value 3.5 had been adopted in the present study, it would not have affected the proportions of patients "at risk." There is no evidence to assume that the number of patients "at risk" would have further reduced had the first sampling interval been 90 min. Blind gastric aspiration, when properly performed, has been shown to be nearly as precise as gastroscopic suction in evacuation of the gastric contents. ${ }^{4}$ As the main proportion of the relatively more acidic gastric contents was aspirated at $60 \mathrm{~min}$, the $90 \mathrm{~min}$ samples mainly represent the juice produced between the two samplings. Possibly, the second sample would have been more acidic, and occasionally more voluminous, had the first evacu- ation not taken place. Fentanyl might have prohibited gastric motility slightly, and retarded the propulsion of the remnant juice not caught at $60 \mathrm{~min}$. However, in a true-to-life situation opioids are generally used during anaesthesia or even as premedicants. In previous studies, the doses of opioids have often remained vaguely defined, and in occasional studies anticholinergic premedication has been in use.

The interval between $\mathrm{H}_{2}$-receptor antagonist administration and gastric juice sampling has rarely been accurately controlled in previous reports, which makes it difficult to make comparisons between studies. Information on the rapidity of the drug effect has been gained using continuous $\mathrm{pH}$ monitoring: intravenous ranitidine $50 \mathrm{mg}$ raised gastric juice $\mathrm{pH}$ (from an initial mean value of 3.5) by one $\mathrm{pH}$ unit in $20 \mathrm{~min}$, and by one and a half $\mathrm{pH}$ unit in $60 \mathrm{~min} .{ }^{5}$ Doses of 50 or $100 \mathrm{mg} \dot{i}$ increased gastric pH from 1.5 to 3.5 in $40-50$ min. ${ }^{6}$ Both results were obtained during anaesthesia. Unfortunately, even timely ( $>90 \mathrm{~min}$ pre-induction) iv ranitidine does not guarantee absolute protection against acid regurgitation during operations prone to provoke regurgitation, as evidenced using a continuous oesophageal $\mathrm{pH}-$ monitoring. ' Peak serum concentrations of ranitidine were attained one to three hours after oral ingestion, and none of 32 patients were at risk $(\mathrm{pH}<2.5$, vol $>25$ $\mathrm{mL}) 3.5 \mathrm{hr}$ after ingestion. ${ }^{8}$ The present results with ranitidine suspension compare favourably with the above findings, possibly owing to the fact that ranitidine suspension is furnished with sodium citrate and bicarbonate.

None of eighty patients was at risk $(\mathrm{pH}<2.5$, vol $>25 \mathrm{ml}$ ), after receiving famotidine $20 \mathrm{mg}$ po at least 
two hours, ${ }^{9}$ or im at least one hour before induction. ${ }^{9,10}$ Further, oral famotidine 20 or $40 \mathrm{mg}$ results in a prophylaxis rate $(\mathrm{pH}>2.5$ ) of about $90 \%$ following a minimum interval of $60 \mathrm{~min}$." The failure rate after famotidine resoriblette was unexpectedly high. The finding may result because the formulation acts through gastric absorption, and not through oral mucosal penetration. In accordance with previous observations, 9,10 famotidine appeared to reduce gastric volume rapidly, though the effect has not been affirmed consistently. ${ }^{1,11}$ This propensity reduces the number of patients "at (the theoretic) risk," even if $\mathrm{pH}$ is considered to be more decisive for pulmonary damage. ${ }^{3}$

It is concluded that after $50-70 \mathrm{~min}$, a water suspension of ranitidine (-citrate-bicarbonate) provides reliable reduction of gastric acidity in healthy adults. Its clinical effect in subjects with an increased risk for gastric acid aspiration, such as obstetric, paediatric, day-case, morbidly obese, trauma, and hyperacidity, cannot be predicted from this study. A resoriblette of famotidine fails to produce a clinically acceptable rate of de-acidification, even though the low gastric volume reduces the risk of dangerous acid aspiration.

\section{Acknowledgments}

The ranitidine and famotidine preparations were kind gifts from Glaxo Pharmaceuticals Oy, and Suomen MSD Oy. The helpful assistance of $\mathrm{B}$. Kuronen, Ph.D., and of nurse anaesthetists is acknowledged.

\section{References}

1 Gallagher EG, White M, Ward S, Cottrell J, Mann SG. Prophylaxis against acid aspiration syndrome. Single oral dose of $\mathrm{H}_{2}$-antagonist on the evening before elective surgery. Anaesthesia 1988; 43: 1011-4.

2 Dubin SA, Silverstein PI, Wakefield $M L$, Jense HG. Comparison of the effects of oral famotidine and ranitidine on gastric volume and pH. Anesth Analg 1989; 69: 680-3.

3 Rocke DA, Brock-Utne JG, Rout CC. At risk for aspiration: new critical values of volume and $\mathrm{pH}$ ? (Letter). Anesth Analg 1993; 77: 666.

4 Søreide E, Sфreide JA, Holst-Larsen H, Steen PA. Studies of gastric content: comparison of two methods. $\mathrm{Br} \mathbf{J}$ Anaesth 1993; 70: 360-2.

5 Takakura K, Harada J, Mizogami M, Goto Y. Prophylactic effects of pirenzepine ( $\mathbf{M}_{\mathbf{L}}$-blocker) on intraoperative stress ulcer. comparison with an $\mathrm{H}_{2}$-blocker. Anesth Analg 1994; 76: 84-6.

6 Atanassoff $P$, Alon $E$, Pasch $T$. Effects of single-dose intravenous omeprazole and ranitidine on gastric $\mathrm{pH}$ during general anaesthesia. Anesth Analg 1992; 75: 95-8.

7 Verbessem D, Camu F, Van de Velde A. Does ranitidine provide protection against acid gastroesophageal reflux? Can J Anaesth 1993; 40: 4-9.

8 Hendolin $H$, Suojaranta-Ylinen $R$, Alhava $E$. Effect of single-dose omeprazole and ranitidine on gastric juice acidity and volume in patients undergoing laparotomy. Acta Anaesthesiol Scand 1993; 37: 484-7.

9 Abe K, Shibala $M$, Demizu A, et al. Effect of oral and intramuscular famotidine on $\mathrm{pH}$ and volume of gastric contents. Anesth Analg 1989; 68: 541-4.

10 Enoki T, Hatano Y, Tsujimura $Y$, Nomura $R$. Attenuation of gastric effects of famotidine by preoperative administration of intravenous fluids. Anesth Analg 1992; 74: 68-71.

11 Talke PO, Solanki DR. Dose-response study of oral famotidine for reduction of gastric acidity and volume in outpatients and inpatients. Anesth Analg 1993; 77: 1143-8. 